\title{
Environmental Audit as a Tool for the Country's Eco-Innovative Development Ensuring*
}

\author{
Yaryna V. SamuseVYchi, IRYNa A. TenYTSKA ${ }^{i i}$
}

\begin{abstract}
The issues of environmental impact reduction became a significant factor in the decision-making process for the development of organizations in EU. Systematic environmental management is an effective way of solving environmental problems arising in organizations' activity. Creating an effective environmental audit system is an essential step in ensuring the regulatory response to the extensive level of environmental pollution. To identify the role of environmental audit in the growth of environmental innovation activity of the country, a number of panel multiple regression dependencies were constructed. The survey database includes data for 28 countries of the European Union for the period 2010-2017. Factor variables of the study were the absolute number of environmental audit organizations, their ratio to the total number of enterprises, and the number of environmental audit and management sites. Resulting variables were the value of the index of eco-innovation of countries and its components. The conducted analysis showed that in the European Union countries, environmental audit is an effective tool for ensuring their eco-innovative development. It is revealed that the biggest positive effect of the growth of the number of environmental audit organizations is manifested in the growth of the scope of ecoinnovation activities and the volume of its financing, as well as the increase of the level of environmental responsibility of the organizations. On the other hand, the increase in the density of environmental audit organizations in relation to the number of enterprises is a factor hampering the country's environmental innovation. Research for different groups of countries proves that increasing the level of eco-innovation progress of states leads to an increase in the positive effects of the functioning of the environmental audit system for the further eco-innovative development. At the same time, the maximum level of impact of environmental audit on the intensity of eco-innovation activity is observed for countries with average level of progress. Thus, the necessity of development of environmental audit in the formulation of Ukraine's environmental policy was proved.
\end{abstract}

Key words: environmental audit, environmental reporting, environmental management, ecoinnovation activities, environment.

JEL Codes: M42, O31, O44, Q56

Introduction. In the face of the global environmental crisis, which is now one of the most real threats to humanity's existence, protecting and improving the quality of the environment are recognized as the world's critical challenges. Those are prerequisites for maintaining the health, well-being, and economic prosperity of the present and future generations. One of the most effective ways to ensure the potential of sustainable development is the limitation of environmental pollutions produced by entities or stimulation of the measures of environment protection and recovery. In this context, the development of environmental audit should be

\footnotetext{
${ }^{i}$ Yaryna V. Samusevych, C.Sc. (Economics), Senior Lecturer of the Department of Accounting and Taxation, Sumy State University;

ii Iryna A. Tenytska, Master's degree at the Department of Accounting and Taxation, Sumy State University.

* The paper was supported by the Ministry of Education and Science of Ukraine and performed the results of the project "Structural-functional multiplex model of ecological tax system building in Ukraine in the context of national security” (registration number 0119U100759).
}

(C) Y. V. Samusevych, I. A. Tenytska, 2020

https://doi.org/10.21272/mer.2020.87.02 
one of the focus of state environmental policy to ensure conditions for stimulation of environmental innovation activities.

Problem statement. The industrialization of society and the growth of industrial development have led to an increase in destructive anthropogenic impact on the environment. This situation has determined a shift in economic development priorities on sustainable development issues and the need to control the environmental impact of commercial entities. Society begins to realize the significance of environmental problems associated with their activities and the need to address them in the short term. Issues of organization of environmental audit and environmental reporting systems are of particular importance in this context. Their effective functioning creates a background for an increase of the rational use of natural resources, reduce the harmful impact of human beings and economic entities on the state of the environment, and increase the environmental responsibility of economic entities. Currently, Ukraine has no successful experience in implementing environmental audits and reporting, while European countries have made significant strides along the way, thereby enhancing the environmental performance of their economies. In the context of the vector of European integration of the domestic economy, these problems are in an area of particular relevance.

The purpose of the paper is an investigation of the relationship between environmental audit and country's eco-innovations progress. The central research hypothesis is that effective environmental reporting and auditing lead to the enhancement of environmentally responsible activities among business entities and causes the increase of country's environmental innovation.

Research results. The current environmental situation requires immediate state intervention and directing all possible resources to reduce the harmful effects of the population and businesses on the environment. In 2019, burning of forest strips to cut shrubs and fallen leaves has become an environmental problem, affecting atmospheric air pollution and deforestation due to the lack of fire control. Also, the most discussed issue is garbage chaos. According to the Interactive Landfill Map, the most significant number of natural landfills is located in Lviv and Donetsk regions, and their number is increasing every year [1]. In Ukraine, there is no administrative and criminal responsibility for excessive emissions of pollutants, no obligation to maintain a separate type of environmental accounting for start-ups in the engineering and chemical industries, no separate form of environmental reporting that will be monitored and verified with actual emissions of harmful substances companies. Hence, there is a need to study and implement several environmental issues at the legislative level, taking into account the experience of the European Union (EU) countries.

Ukraine has started cooperating with the EU since 1998 in terms of preservation of natural sources and climate change, in particular concerning the prevention of air and water pollution, the reduction of volumes and the safe use of industrial waste, the protection of forests, the protection of biological diversity and their efficient use and management of natural resources and the implementation of the United Nation Convention on Environmental Impact in a Transboundary Context, etc. [2]. At the state level, most domestic laws on business provide a mechanism of compensation for damage caused by environmental pollution. Still, they are not sufficient to ensure the prevention and elimination of damage caused by natural habitat. Since independence, Ukraine has often changed the regulatory framework for environmental safety, tax rates, and programs for the development of certain types of resources.

In our view, particular attention should be paid to the Law of Ukraine "On environmental audit” [3], which provides two forms of environmental audit: voluntary and mandatory. 
However, the deepening in the issue showed that even some of the Big Four audit firms are not represented as an environmental auditor. For independent auditors, the search for such experts did not yield results. The determined law contains the fundamental rights and obligations of customers and contractors, allocates environmental audit to external and internal, distinguishes the procedure of environmental audit. Still, the law does not mention responsibility for violations of the rules of such legislation. On this basis, it can be stated that the obligation to fulfill it is zero. Therefore, such a regulatory act requires revision and fundamental changes to the responsibility, clarity of the definition of the environmental audit program. Besides, since the law was adopted in 2004, it is obsolescent. Alterations to specific sections of a particular law should entail changes in the Tax and Criminal Codes of Ukraine. The Accounting Standards should also be reviewed, in particular in terms of reflecting environmental income and expenses, generating environmental profit, and using it. It is also necessary to amend the Instruction on the application of the Accounts Plan No. 291 and to separate an account for environmental costs, revenues, liabilities, and profits. An integral part of such changes is the development of methodological recommendations on the features of ecological accounting at enterprises. There are many laws in Ukraine in this area, but the correct application and interpretation of its requirements is a problem.

Another problematic aspect is the Law of Ukraine "On Environmental Impact Assessment" [4]. It does not include a separate section that should provide the creation of a national automated information system for preventing and eliminating environmental damage, so this mechanism will accelerate the collection of environmental reports (which should be mandatory for all businesses regardless of the type of activity), will allow to accurately assess the level of impact of the enterprises of certain industries on the environment. On this basis, programs should be developed to reduce the amount of pollution by individual types of households and to increase environmental responsibility among Ukrainians, implementing the experience of EU countries.

The main challenges for the government are resolving and regulating the following issues:

1) to improve the legal framework for environmental management;

2) to define the mandatory character and conditions of ecological reports preparing and develop their form;

3) to establish a regulatory framework for environmental audit obligations and liability for violations of legal requirements;

4) to strengthen the mechanisms for setting ecological priorities;

5) to improve the efficiency of ecological institutions by enhancing coordination and streamlining responsibilities across institutions;

6) to increase the capacity for environmental management at the regional level;

7) to expand and strengthen the implementation of a range of environmental policy tools and mechanisms to develop good environmental practices in line with EU requirements;

8) to enhance environmental and public participation management.

Therefore, solving the enlightened problems will create a background to improve the environmental situation in Ukraine, initiate environmental responsibility of entrepreneurs and will help Ukraine to enter new competitive markets, since the issue of preservation of natural amenities is one of the most important areas, and the rapid development of the industrial sector, the imperfection of legislation and obsolete equipment factors of significant anthropogenic impact on the environment.

Based on the identified shortcomings of the national environmental legislation and problems with defining the procedures and processes of environmental reporting and audit, the 
task is to study the effectiveness of environmental reporting and environmental audit and to determine their impact on the level of eco-innovation in European countries. Therefore, for further study, three hypotheses were put forward:

- registration of organizations and sites of environmental management and environmental audit has a positive impact on the eco-innovation indicator;

- registration of environmental management and environmental audit organizations and sites reduces the share of environmental tax revenue in GDP;

- the impact of registered organizations and sites on eco-innovation performance differs for countries with different levels of eco-innovation.

To test the above hypotheses we use the data from World Bank [7] and Eurostat [5, 6], in particular: the Environmental Innovation Index (IEI); investment in the development of environmental innovations (IDEI); allocation of resources and expenditures for government research (AREGR); general research staff (LRS); the total cost of green early investment per capita (TCpc); eco-innovation activities (EIA); enterprises that have innovated with the environmental benefits of the enterprise (EIEbe); enterprises that have introduced innovation with environmental benefits derived from the end consumer (EIIbc); organizations that comply with ISO 14001 (ISO); eco-innovation results (EIR); patents related to eco-innovation (EP); scientific publications relating to environmental innovation (SPREI); Eco-innovation media (Media); Resource Efficiency Outcomes (REO); material productivity (MP); water productivity (WP); energy efficiency (EEf); intensity of greenhouse gas emissions (IGG); socio-economic outcomes (SEO); export of products from the eco-industry (EPE); employment in eco-industries (EEi); turnover in eco-industries (Tei).

To assess the impact of the number of registered organizations and sites of environmental management and environmental audit on eco-innovation indicators, a panel regression modeling (fixed effects model) was used by Stata software, which allowed estimating the average level of links for a sample of $28 \mathrm{EU}$ countries over the study period covering 2010-2017.

The results of calculations of the impact of registered environmental management and environmental audit organizations number on eco-innovation performance are shown in Table 1.

Based on the table above, we can conclude that with the increase in the number of registered environmental management and environmental audit organizations per unit determinates statistically significant increase in following indicators: Eco-Innovation Index (by 0.029 points), eco-government spending (by 0.060 points), eco-innovation activities (by 0.080 points), organizations registered ISO 14001 (by 0.071 points), media related to ecoinnovation (by 0.050 points), energy efficiency (by 0.017 points). Changes in other indicators were statistically insignificant and therefore need further investigation.

On the basis of the Eurostat Eco-Innovation Index, EU countries were allocated to those that are leaders of eco-innovations (Sweden, Finland, Germany, Austria, Luxembourg, Denmark), those countries that comply with the environmental standards (Czech Republic, Portugal, Slovenia, Spain, the United Kingdom, Lithuania, Croatia, Italy, Ireland, the Netherlands, France) and those starting their eco-innovation activity (Greece, Estonia, Cyprus, Slovakia, Hungary, Latvia, Bulgaria, Malta, Romania, Poland, Belgium). Tables 2-4 summarize the calculated data, taking into account the relationship between the indicators at the significance level of 90-95\%. These tables show that the relationships between many productive features are strong, which indicates the quality of the data collected and the prospects of implementation of the results. 
Я. В. Самусевич, І. А. Теницька.

Екологічний аудит як інструмент забезпечення екологічного інноваційного розвитку країни

Table 1

Results of the assessment of the impact of registered environmental management and environmental audit organizations on eco-innovation indicators during 2010-2017

\begin{tabular}{|l|r|r|r|r|r|r|}
\hline Resulting variable & $\begin{array}{c}\text { Coefficient } \\
\text { of influence }\end{array}$ & $\begin{array}{c}\text { Standard } \\
\text { error }\end{array}$ & $\mathrm{Z}$ & $\mathrm{P}\rangle|\mathrm{z}|$ & $\begin{array}{c}\text { Lower } \\
95 \%\end{array}$ & $\begin{array}{c}\text { Upper } \\
95 \%\end{array}$ \\
\hline IEI & 0.029 & 0.015 & 1.98 & 0.048 & 0.000 & 0.057 \\
\hline IDEI & 0.034 & 0.027 & 1.27 & 0.205 & -0.019 & 0.087 \\
\hline AREGR & 0.060 & 0.024 & 0.48 & 0.013 & 0.0127 & 0.108 \\
\hline LRS & 0.004 & 0.029 & 0.13 & 0.894 & -0.055 & 0.063 \\
\hline TCpc & 0.021 & 0.054 & 0.38 & 0.702 & -0.085 & 0.126 \\
\hline EIA & 0.080 & 0.021 & 3.89 & 0.000 & 0.040 & 0.120 \\
\hline EIEbe & 0.001 & 0.000 & 1.52 & 0.128 & -0.000 & -0.003 \\
\hline EII & 0.021 & 0.025 & 0.83 & 0.406 & -0.028 & 0.069 \\
\hline ISO & 0.071 & 0.035 & 2.05 & 0.041 & 0.003 & 0.138 \\
\hline EIR & 0.037 & 0.028 & 1.34 & 0.180 & -0.171 & 0.091 \\
\hline EP & 0.034 & 0.037 & 0.92 & 0.356 & -0.038 & 0.106 \\
\hline SPREI & -0.028 & 0.040 & -0.70 & 0.483 & -0.105 & 0.050 \\
\hline Media & 0.050 & 0.025 & 2.04 & 0.041 & 0.002 & 0.098 \\
\hline REO & 0.018 & 0.17 & 1.06 & 0.291 & -0.015 & 0.051 \\
\hline MP & -0.011 & 0.030 & -0.38 & 0.705 & -0.706 & 0.048 \\
\hline WP & 0.002 & 0.011 & 0.18 & 0.861 & -0.019 & 0.023 \\
\hline EEf & 0.048 & 0.020 & 2.39 & 0.017 & 0.009 & 0.879 \\
\hline IGG & 0.024 & 0.018 & 1.33 & 0.184 & -0.011 & 0.059 \\
\hline SEO & 0.019 & 0.017 & 1.13 & 0.256 & -0.014 & 0.052 \\
\hline EPE & 0.034 & 0.024 & 1.44 & 0.151 & -0.013 & 0.082 \\
\hline EEi & 0.004 & 0.029 & 0.14 & 0.887 & -0.533 & 0.062 \\
\hline Tei & 0.018 & 0.021 & 0.82 & 0.409 & -0.024 & 0.060 \\
\hline
\end{tabular}

Source: authors' calculations according to the data from $[5,6,7]$

Table 2

Results of estimation of influence of absolute and relative index of number of registered organizations, sites of environmental management and environmental audit on indicators of eco-innovation in the leading countries during 2010-2017

\begin{tabular}{|c|c|c|c|c|c|c|}
\hline Resulting variable & $\begin{array}{l}\text { Coefficient } \\
\text { of influence }\end{array}$ & $\begin{array}{l}\text { Standard } \\
\text { error }\end{array}$ & $\mathrm{Z}$ & $\mathrm{P}>|\mathrm{z}|$ & Lower 95 \% & Upper $95 \%$ \\
\hline \multicolumn{7}{|c|}{ The number of registered environmental management and environmental audit organizations } \\
\hline EIF & 0.044 & 0.025 & 1.78 & 0.075 & -0.004 & 0.093 \\
\hline EIEbe & 0.006 & 0.002 & 3.40 & 0.001 & 0.003 & 0.010 \\
\hline EII & 0.080 & 0.042 & 1.89 & 0.059 & -0.003 & 0.162 \\
\hline SPREI & -0.129 & 0.042 & -3.10 & 0.002 & -0.212 & -0.047 \\
\hline WP & -0.003 & 0.001 & -2.16 & 0.031 & -0.006 & -0.000 \\
\hline
\end{tabular}

The ratio of registered environmental management and environmental audit organizations to the total enterprises' number

\begin{tabular}{|c|c|c|c|c|c|c|}
\hline & & & & & & \\
\hline ISO & 143413.9 & 82445.0 & 1.74 & 0.082 & -18175.28 & 305003.1 \\
\hline SPREI & -301361.1 & 77094.17 & -3.91 & 0.000 & -452462.9 & -150259.3 \\
\hline WP & -1468.876 & 842.58 & -1.74 & 0.081 & -3120.308 & 182.55 \\
\hline IGG & -52888.92 & 22835.58 & -2.32 & 0.021 & -97645.85 & -8132 \\
\hline \multicolumn{7}{|c|}{ The number of registered environmental management and environmental audit sites } \\
\hline AREGR & 0.052 & 0.031 & 1.65 & \begin{tabular}{|l|}
0.098 \\
\end{tabular} & -0.010 & 0.11 \\
\hline EII & 0.057 & 0.027 & 2.11 & 0.035 & 0.004 & 0.10 \\
\hline SPREI & -0.092 & 0.026 & -3.53 & 0.000 & -0.142 & -0.40 \\
\hline
\end{tabular}


Source: authors' calculations according to the data from [5, 6, 7]

Thus, the data presented indicate that an increase in absolute numbers of registered environmental management and environmental audit organizations in the leading countries per unit will contribute to the rise in eco-innovation performance (by 0.044 points), internal environmental benefits (by 0.006 points) and external environmental benefits (by 0.080 points). In terms of relative indicators, an increase in such organizations per unit mostly will lead to a reduction in eco-innovation in the leading countries. The only exception is an effect obtained for the registration following ISO 14001.

The next step is to analyze similar indicators for countries that comply with environmental standards (Table 3). Calculations' results demonstrate positive relationships between absolute and relative indicators of environmental management and audit organizations and sites and eco-innovations parameters. That allowed substantiating the importance of environmental audit for eco-oriented countries' development. The prospects for the governments of these countries are to develop environmental programs to support green entrepreneurship, to form separate green budgets for individual activities, to adopt environmental reporting and auditing legislation, to identify incentives to implement eco-innovation based on the experience of leading countries. Attention should also be paid to EU countries embarking on their ecoinnovation path (Table 4).

Table 3

Results of the estimation of the impact of the number of registered organizations, and sites on the eco-innovations for the countries that comply with environmental standards during 2010-2017

\begin{tabular}{|c|c|c|c|c|c|c|}
\hline Resulting variable & $\begin{array}{l}\text { Coefficient } \\
\text { of influence }\end{array}$ & $\begin{array}{c}\text { Standard } \\
\text { error }\end{array}$ & $\mathrm{Z}$ & $\mathrm{P}>|\mathrm{z}|$ & $\begin{array}{c}\text { Lower } \\
95 \%\end{array}$ & Upper95 \% \\
\hline \multicolumn{7}{|c|}{$\begin{array}{c}\text { An absolute indicator of the number of registered environmental management and environmental audit } \\
\text { organizations }\end{array}$} \\
\hline AREGR & 0.079 & 0.026 & 3.02 & 0.002 & 0.028 & 0.130 \\
\hline EIA & 0.073 & 0.030 & 2.47 & 0.013 & 0.015 & 0.131 \\
\hline ISO & 0.121 & 0.041 & 2.98 & 0.003 & 0.042 & 0.201 \\
\hline Media & 0.091 & 0.023 & 4.06 & 0.000 & 0.047 & 0.136 \\
\hline EEf & 0.051 & 0.028 & 1.82 & 0.069 & -0.004 & 0.106 \\
\hline \multicolumn{7}{|c|}{ Relative number of registered Environmental management and environmental audit organizations } \\
\hline IEI & 78467.01 & 45960.91 & 1.71 & 0.088 & -11614.72 & 168548.7 \\
\hline AREGR & 221664 & 82855.37 & 2.68 & 0.007 & 59270.51 & 384057.6 \\
\hline EIA & 250769.7 & 84453.01 & 2.93 & 0.003 & 83284.91 & 418254.5 \\
\hline ISO & 357237.9 & 122763.1 & 2.91 & 0.004 & 116626.6 & 697849.2 \\
\hline Media & 332332.4 & 97568.89 & 3.41 & 0.001 & 141100.9 & 523563.9 \\
\hline EEf & 231300.1 & 82412.87 & 2.81 & 0.005 & 69773.89 & 392826.4 \\
\hline \multicolumn{7}{|c|}{ Number of registered environmental management and environmental audit sites } \\
\hline AREGR & 0.040 & 0.018 & 2.20 & 0.027 & 0.004 & 0.076 \\
\hline EIA & 0.056 & 0.021 & 2.62 & 0.009 & 0.014 & 0.098 \\
\hline ISO & 0.112 & 0.028 & 3.94 & 0.000 & 0.056 & 0.167 \\
\hline Media & 0.637 & 0.019 & 3.42 & 0.001 & 0.272 & 0.100 \\
\hline EEf & 0.038 & 0.020 & 1.94 & 0.052 & -0.000 & 0.077 \\
\hline
\end{tabular}

Source: authors' calculations according to the data from $[5,6,7]$

The calculations show that the number of registered sites the environmental management and environmental audit affect only eco-innovations' results. So increasing the indicator by the unit will increase the sufficient value by 0.045 points. 
Я. В. Самусевич, І. А. Теницька.

Екологічний аудит як інструмент забезпечення екологічного інноваційного розвитку країни

Table 4

Results of the estimation of the impact of the number of registered organizations, and sites on the eco-innovations for the countries starting eco-innovations during 2010-2017

\begin{tabular}{|c|c|c|c|c|c|c|}
\hline Resulting variable & $\begin{array}{l}\text { Coefficient } \\
\text { of influence }\end{array}$ & $\begin{array}{c}\text { Standard } \\
\text { error }\end{array}$ & Z & $\mathrm{P}>|\mathrm{z}|$ & Lower $95 \%$ & Upper 95 \% \\
\hline \multicolumn{7}{|c|}{ An absolute indicator of the number of registered environmental management and environmental audit organizations } \\
\hline IEI & -0.231 & 0.123 & -1.89 & 0.059 & -0.472 & 0.008 \\
\hline IDEI & -0.401 & 0.209 & -1.91 & 0.056 & -0.810 & 0.009 \\
\hline EIA & -0.291 & 0.121 & -2.40 & 0.016 & -0.528 & -0.054 \\
\hline ISO & -0.978 & 0.377 & -2.60 & 0.009 & -1.0716 & -0.240 \\
\hline SPREI & 1.037 & 0.543 & 1.91 & 0.056 & -0.027 & 2.102 \\
\hline PEO & 0.278 & 0.106 & 2.63 & 0.009 & 0.071 & 0.487 \\
\hline WP & 0.018 & 0.014 & 1.75 & 0.080 & -0.002 & 0.039 \\
\hline EEf & 0.457 & 0.223 & 2.05 & 0.040 & 0.021 & 0.893 \\
\hline IGG & 0.351 & 0.140 & 2.50 & 0.012 & 0.076 & 0.625 \\
\hline SEO & -0.0691 & 0.383 & -1.80 & 0.071 & -1.443 & 0.060 \\
\hline EPE & -1.030 & 0.470 & -2.19 & 0.028 & -1.95 & -0.109 \\
\hline \multicolumn{7}{|c|}{ Relative number of registered environmental management and environmental audit organizations } \\
\hline IEI & -25821.19 & 8695.75 & -2.97 & 0.003 & -42864.54 & -8777.83 \\
\hline EIA & -25252.56 & 8503.389 & -2.97 & 0.003 & -41918.9 & -8586.229 \\
\hline ISO & -78160.85 & 28025.35 & -2.79 & 0.005 & -133289.5 & -23232.17 \\
\hline EP & -50742.92 & 22537.62 & -2.25 & 0.024 & -94915.83 & -6570.05 \\
\hline SPREI & 160055.7 & 42155.53 & 3.80 & 0.000 & 77432.39 & 242679 \\
\hline IGG & 14886.67 & 8743.659 & 1.70 & 0.089 & -2250.58 & 32023.93 \\
\hline SEO & -95340.45 & 32806.8 & -2.91 & 0.004 & -159640.66 & -31040.31 \\
\hline EPE & -174259 & 36261.62 & -4.81 & 0.000 & -245330.4 & -103187.5 \\
\hline Tei & -76406.29 & 41102.61 & -1.86 & 0.063 & -156965.9 & 4153.34 \\
\hline \multicolumn{7}{|c|}{ Number of registered environmental management and environmental audit sites } \\
\hline EIR & 0.045 & 0.026 & 1.71 & 0.088 & -0.007 & 0.096 \\
\hline
\end{tabular}

Source: authors' calculations according to the data from $[5,6,7]$

Regarding the absolute and relative indicator of the number of registered environmental management and environmental audit organizations, half of the total indicators are statistically significant. In such countries, government policy should be concentrated on monitoring of greenhouse gas emissions, water, and energy efficiency, control of eco-innovation investments.

Conclusions. Based on the conducted analysis, we can conclude that the hypotheses have been partially confirmed. Thus, the increase in absolute numbers of registered organizations and sites of environmental management and environmental audit causes the growth of most of the eco-innovations' indicators. Assessing the relative parameter of environmental management and audit activity, we note the reversed situation. So, the ratio of environmental management and environmental audit organizations to the total number of registered enterprises increase leads to a reduction in environmental innovation activities and results.

The hypothesis regarding the differentiated impact of environmental management and environmental audit registered organizations and a site on eco-innovation indicators in different groups of the EU countries is fully confirmed. Therefore, the study shows that environmental reporting and environmental audit is an integral tool for monitoring and regulation of the environmental performance of organizations, which has a positive impact not only on the level of environmental awareness of the population but also a for the increase of the eco-innovation performance among EU countries. 
At the same time, the results identified for countries with different levels of eco-innovation has shown that in developing an environmental audit and reporting system, Ukraine should choose its own approach to build a system that will maximize its impact, in accordance with the actual state of the environment responsibilities in the country.

\section{References}

1. Interactive landfill site map: official website. Retrieved from https://ecomapa.gov.ua/?layer=mss.

2. Environmental protection. Representation of Ukraine to the European Union and the European Atomic Energy Community: official website. Retrieved from https://ukraineeu.mfa.gov.ua/ua/ukraine-eu/sectoral-dialogue/environment.

3. Zakon Ukrainy Pro ekologichnyi audyt : pryiniatyi 24 cherv. 2004 roku № 1862-IV [Law of Ukraine On Environmental Audit Activity from June 24 2004, № 1862-IV]. (2004, June 24). Vidomosti Verkhovnoi Rady Ukrainy, 45, art. 500. Retrieved from https://zakon.rada.gov.ua/laws/show/186215 [in Ukraine].

4. Zakon Ukrainy Pro otsinku vplyvu na dovkillia : pryiniatyi 23 travn. 2017 roku № 2059-VIII [The Law of Ukraine On Environmental Impact Assessment Activity from May 23 2017, № 2059-VIII] (2017, May 23). Vidomosti Verkhovnoi Rady Ukrainy, 29, art. 315 Retrieved from https://zakon.rada.gov.ua/laws/show/2059-19 [in Ukraine].

5. ECO-INNOVATION at the heart of European policies. European Commission: official website. Retrieved from https://ec.europa.eu/environment/ecoap/indicators/index_en.

6. Environmental tax revenues Eurostat. Retrieved from http://appsso.eurostat.ec.europa.eu/nui/show.do?dataset=env_ac_tax\&lang=en.

7. World Development Indicators The World Bank Retrieved from http://databank.worldbank.org/data/reports.aspx?source=world-development-indicators.

Manuscript received 29 November 2019

\section{Экологический аудит как инструмент обеспечения экологически инновационного развития} страны

\section{ЯРИНА ВАЛЕНТИНОВНА САМУСЕВИЧ*, ИРИНА АНАТОЛЬЕВНА ТЕНИЦКАЯ**,}

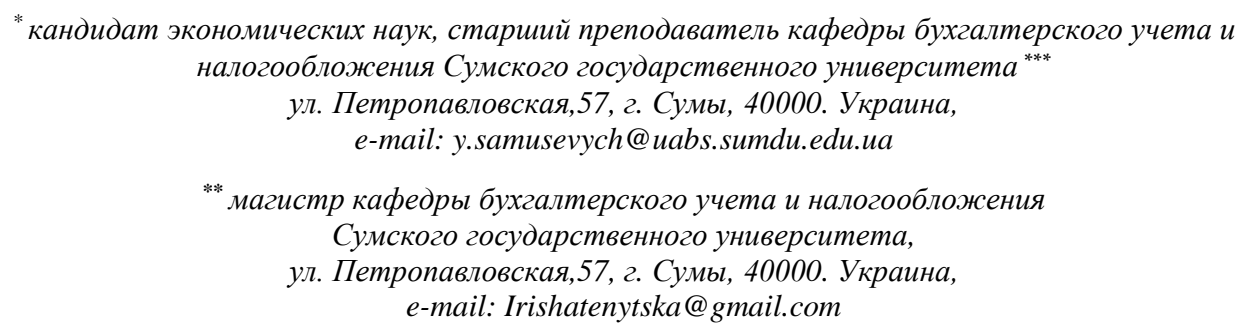

Вопросы уменьшения воздействия на окружающую среду стали главным фактором для принятия решений по развитию организаций в странах Европейского Союза. Эффективным способом решения экологических проблем, возникающих в деятельности организаций, является систематическое управления окружающей средой. Создание эффективной системы экологического аудита является важным этапом обеспечения оперативного реагирования на чрезмерный уровень загрязнения окружающей среды. Для выявления роли экологического аудита в обеспечении роста экологической инновационной активности страны был построен ряд панельных множественных регрессионных зависимостей. Информационная база исследования включает данные для 28 стран Европейского Союза за период 2010-2017 годов. Факторными 
Я. В. Самусевич, І. А. Теницька.

Екологічний аудит як інструмент забезпечення екологічного інноваційного розвитку країни

переменными исследования стали абсолютное количество организаций экологического аудита, их соотношение к общему количеству предприятий и количество сайтов экологического аудита и менеджмента. Результативными переменными выступают значения индекса экологической инновационности стран и его компонентов. Проведенный анализ показал, что в странах Европейского Союза экологический аудит является эффективным инструментом обеспечения их экологически инновационного развития. Выявлено, что наибольший положительный эффект роста количества организаций экологического аудита проявляется в росте масштабов экоинновационной деятельности и объемов ее финансировании, а также повышении уровня экологической ответственности организаций. С другой стороны, рост плотности организаций экологического аудита относительно численности предприятий является фактором, сдерживающим экологические инновации страны. Исследования для различных групп стран доказывает, что рост уровня эко-инновационного прогресса стран обусловливает повышение положительных эффектов функционирования системы экологического аудита. При этом максимальный уровень воздействия экологического аудита на интенсивность эко-инновационной активности наблюдается для стран со средним уровнем прогресса. Таким образом доказана необходимость развития экологического аудита при формировании экологической политики Украины.

Ключевые слова: экологический аудит, экологическая отчетность, экологический менеджмент, экологически инновационная деятельность, окружающую природную среду

\section{Mechanism of Economic Regulation, 2020, No 1, 38-47 \\ ISSN 1726-8699 (print)}

\section{Екологічний аудит як інструмент забезпечення екологічно інноваційного розвитку країни}

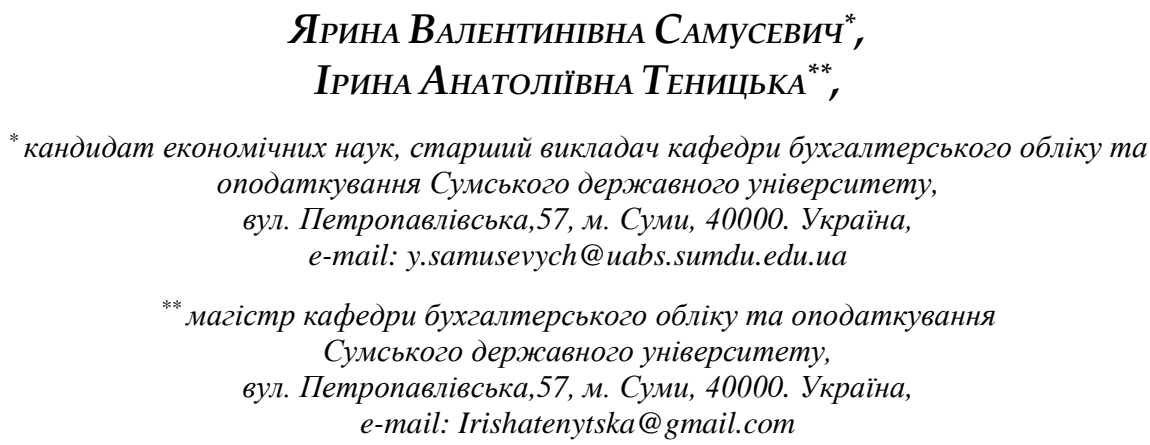

Питання зменшення впливу на навколишнє середовище стало головним фактором для прийняття рішень щодо розвитку організацій країнах Європейського Союзу. Ефективним способом вирішення екологічних проблем, що виникають в діяльності організацій, $\epsilon$ систематичне управління довкіллям. Створення ефективної системи екологічного аудиту $є$ важливим етапом забезпечення оперативного реагування на надмірний рівень забруднення навколишнього природного середовища. Для виявлення ролі екологічного аудиту в зростанні екологічної інноваційної активності країни було побудовано ряд панельних множинних регресійних залежностей. Інформаційна база дослідження включає дані для 28 країн Європейського Союзу за період 2010-2017 років. Факторними ознаками дослідження стали абсолютна кількість організацій екологічного аудиту, їх співвідношення до загальної кількості підприємств та кількість сайтів екологічного аудиту та менеджменту. Результативними ознаками виступають значення індексу екологічної інноваційності країн та його компонентів. Проведений аналіз засвідчив, що в країнах Європейського Союзу екологічний аудит $\epsilon$ ефективним інструментом забезпечення їх екологічного інноваційного розвитку. Виявлено, що найбільший позитивний ефект зростання кількості організацій екологічного аудиту проявляється у зростанні 
масштабів еко-інноваційної діяльності та обсягів іiі фінансуванні, а також підвищенні рівня екологічної відповідальності організацій. 3 іншого боку зростання густоти організацій екологічного аудиту відносно чисельності підприємств є фактором, що стримує екологічні інновації країни. Дослідження, проведені для різних груп країн доводять, що зростання рівня екоінноваційного прогресу країн обумовлює підвищення позитивних ефектів функціонування системи екологічного аудиту. При цьому максимальний рівень впливу екологічного аудиту на інтенсивність еко-інноваційної активності спостерігається для країн з середнім рівнем прогресу. Таким чином доведено необхідність розвитку екологічного аудиту при формуванні екологічної політики України.

Ключові слова: екологічний аудит, екологічна звітність, екологічний менеджмент, екологічноінноваційна діяльність, навколишнє природне середовище

JEL Codes: M42, O31. O44, Q56

Table: 4; Figure: 0; References: 7

Language of the article: English

תimepamypa

1. Interactive landfill site map: official website. Режим доступу : https://ecomapa.gov.ua/?layer=mss.

2. Environmental protection. Representation of Ukraine to the European Union and the European Atomic Energy Community: official website. Retrieved from https://ukraineeu.mfa.gov.ua/ua/ukraine-eu/sectoral-dialogue/environment.

3. Закон України «Про екологічний аудит» від 24 червня 2004 року № 1862-IV [Електронний ресурс] // Відомості Верховної Ради України (ВВР). - 2004. - № 45, ст. 500. - Режим доступу: https://zakon.rada.gov.ua/laws/show/1862-15.

4. Закон України «Про оцінку впливу на довкілля» від 23 травня 2017 року № 2059-VIII [Електронний ресурс]. // Відомості Верховної Ради України (ВВР). - 2017. - № 29, ст. 315. Режим доступу: https://zakon.rada.gov.ua/laws/show/2059-19.

5. ECO-INNOVATION at the heart of European policies. European Commission: official website. Retrieved from https://ec.europa.eu/environment/ecoap/indicators/index_en.

6. Environmental tax revenues Eurosta. Retrieved from http://appsso.eurostat.ec.europa.eu/nui/show.do?dataset=env_ac_tax\&lang=en.

7. World Development Indicators The World Bank Retrieved from http://databank.worldbank.org/data/reports.aspx?source=world-development-indicators. 